\title{
The Inevitable Otherness behind the Mask in T. E. Lawrence's Seven Pillars of Wisdom
}

https://doi.org/10.33806/ijaes2000.21.2.12

\author{
Arkan Naser Hussain, Hassan Qanood Jabir and Noor Kadhoum Jawad \\ The General Directorate of Education in Al-Qadisiyah Province, Ministry \\ of Education, Iraq
}

\begin{abstract}
The concept of "Otherness" can be perceived in several European narrative writings. Despite the complications that the definition of the term might imply, most of the works presented have a deliberate emphasis on presenting the deleterious chauvinisms concerning the Orient. In Orientalist literature, one can notice the insistence on keeping the potentials and differences between the East and the West. The reader is presented with a variety of events that serve to indicate the Western superiority over the East in all aspects. In this conception, the social, philosophical and cultural structure of the Eastern societies is to be considered inferior to the Western one. Therefore, negation is viewed as the only way of comparison between the two. This study examines T.E. Lawrence's Seven Pillars of Wisdom (SPW) as a typical orientalist text. Moreover, it sheds light on the conflicting powers in the personal identity of Lawrence himself. Through evidences and insights, it argues that though Lawrence contends that he has written a travel narrative in SPW, the novel is an autobiography of an Orientalist imperial agent, a White Man who continues the tradition of reductionism and stereotyping and technically rests on Orientalist strategies.
\end{abstract}

Keywords: Imperialism, orientalism, otherness, postmodernism, reductionism, stereotyping.

\section{Introduction}

Travel narratives, widely considered as a hybrid genre, often introduce the records of the activity of a person who visits different places, people, and cultural categories. Travel, a journey that has the documentary sensibility of the everyday life, delivers a mirroring image and offers valuable insights about the cultural, social, and philosophical worlds of different societies. Travel narrative, whether descriptive, informative or episodic, could represent a bridge that makes truthful statements of the traveller's experiences.

Literature of the oriental is often determined by the heavy emphasis on the binary opposition 'orient/occident, which refers to the 'East/West.' Yet, it is disturbing to notice that what persists popular literature is the negative construction of the orient; therefore, many literary texts, with preconceived cultural perspectives, try to generate realities and destructive representation of the East. This representation can be witnessed when Western travel narrative shifted to the postcolonial change, subjective concerns of war, and violence. Works witnessed adaptation to the chaotic, abrupt political and cultural events of the 
imperialized realm. In 1926, T. E. Lawrence published SPW, although he lost the main manuscript in the train forever and depended on notes, articles and memory to build the first draft. The novel is an autobiographical description of the experiences of Lawrence ("Lawrence of Arabia") while serving as a liaison officer with rebel forces during the Arab Revolt against the Ottoman Turks of 1916 to 1918. Written with evocative and graceful prose, it represents the work upon which Lawrence's reputation largely rests on. However, much debate has surrounded the work and its accuracy.

$S P W$ begins with an overview of Arab history, starting with a short description of the Muslim expansion in the seventh century, and outlining events through which the Arabs were eventually overthrown by the Turks in the eleventh century. The Turkish Empire was still ruling Arabia during the First World War, allied with the Germans against Britain and France. In 1916 Sherif Hussein of Mecca (leader of the Arabs) declared a rebellion against the Turks. Lawrence was sent to Mecca by the British military command in Cairo to conduct a fact-finding mission and help in the success of the Arab revolt, which will help defeat Turkey. The quality of his reports and the strong relationships he formed with the Arab leaders led to his ultimate assignment as a British liaison officer, serving with forces of Emir Feisal, one of Hussein's four sons. Lawrence describes Feisal as the only Arab leader with the "necessary fire" to successfully lead the revolt. He chronicles the Arab revolt starting with his 1916 mission to Mecca, describing his efforts to help Feisal unify the feuding Arab tribes against the Turks. He recounts missions of very long distance on camel back, traversing the harshest desert terrain through extremes of cold and heat. He describes several successful guerrilla campaigns against the Turkish railroad that played a key role in the ultimate victory. $S P W$ ends with the Arab army's victorious capture of Damascus, but that is not the end of the story. Immediately after the fall of Damascus, Lawrence returned to England. In 1919 he served in the British Delegation at the Paris Peace Conference, working closely with Feisal to secure Arab independence. Arab leaders were lead to believe the British were sincere in their desire to free the Arab people from the Turkish yoke. Unfortunately for the Arabs, the British agenda was governed by the politics of empire, not the aspirations of the Arab people. Several times in $S P W$ Lawrence expresses his shame at dealing with the Arabs under false pretenses. According to the Sykes-Pico agreement, of which Lawrence claims to have had no knowledge, the French were determined to rule Syria, while the British had similar ambitions in Palestine and Iraq. In the ultimate betrayal, Syria, Palestine and Iraq were given over to France and Britain as mandated territories - colonies in all but name. Feisal, who ruled in Damascus after the war, was ousted by the French in 1920.

\section{Argument, Framework and Methodology}

$S P W$ is highly significant to Eastern scholars, for the lessons one can get from it due to its relevance to contemporary situations. For example, it advises Arabs not to trust Western motives. Lawrence himself organized the revolt of the Arab against the Ottoman Empire and took part in raids with the Arab forces, such as 
the raids on the Damascus-Medina railway. Nevertheless, Lawrence's book has no indication that Islamic religious enthusiasm participated in the Arab cause. The British government promised to help Sherif Hussein, Emir of Mecca and king of Arabs, build an independent nation but did not fulfill that promise. It becomes clear from notes exchanged in 1916 among Russia, France, and Britain, known later as the Sykes-Picot Agreement that the Arab revolt had begun on false pretenses. The Agreement planned to give independence to Arabian Peninsula and divide control over Arab countries of the Middle East for political and economic privileges (Hill 2011: 63).

The present study argues that $S P W$ is an Orientalist text in the true sense of the term. What Lawrence has written in $S P W$ is neither a history nor a typical travel narrative but a private fiction full of half-truths, making him an imperial agent, an orientalist White Man. Thus, the study is structured to deal with three fundamental ideas in Lawrence's novel: the intrinsic traits of Orientalism, Lawrence's psychological status as a character-writer, and the Orientalist strategies followed in the book. In fact, Lawrence continues a tradition of stereotypical visions and reductive categories about the Orient which dates back to the time sof Middle Ages. This Orientalist tradition is critically known by its crystal-clear demarcation lines and idiosyncratic traits.

Unfortunately, Lawrence becomes an unfaithful transcriber of events, which reveals that the author becomes the victim of his own writing. His failure to be a sincere man renders his own hypocrisy. Hence, he suffers psychologically due to split opposites between his legendary history and the imaginative investment of an Orientalist text. The kind of schizophrenia he experiences is the outcome of his inability to fix his own identity. To meet this end of control over the Orient, Lawrence as a character and a writer adopts certain Orientalist strategies. As a character, he adopts improvisation which entails role-playing. As a writer, he inserts the Western element in almost everything in order to change the unknown Arabia and its experience into the familiar Western counterpart.

The study is conducted following a descriptive-analytical methodology. It bases on Orientalism as a backbone for its critical analysis whereas it tries to allocate a certain epistemological continuity in the colonial imagination of the Orient.

\section{3. $S P W$ as an Orientalist Novel}

The term Orientalism can be primarily defined as a discourse that dealt with Eastern societies, literature, cultures, and languages by Western scholars. Though it is believed that the existence of Orientalism is as early as the Middle Ages, the interest in the East was the result of the great changes of the nineteenth century, mainly the colonial expansion. Nevertheless, it is important to note that Orientalist discourse is much more than just rationalization or justification of the colonial rule after many parts of the Eastern world were conquered by European colonizers. According to Edward Said, "To say that Orientalism was a rationalization of colonial rule is to ignore the extent to which colonial rule was justified in advance by Orientalism, rather than after the fact" (Said, 1978: 39). 
Consequently, Oriental fiction began to comprise a body of beliefs, doctrines, ideas, and texts based on assumptions produced by the Western thinking about the East. What is common about Oriental fiction is the inculcation of the Orientals as irrational, different, and depraved while the Occidentals are regarded as normal, virtuous, mature, and rational (Yun 2012: 31-32). In Orientalism, Said refers to several fictional works demonstrating how Orientalism often override class, gender, and stylistic limitations.

From a literary perspective, travel narrative represents a source of experience as the hero moves from one cultural category to another. The journey is considered a bridge that reflects the objective and truthful experiences and observations. However, Lawrence's book is intentionally written to suit the Western taste. In other words, the Orient presented in $S P W$ is the result of a long period of hatred and negative prejudices. Instead of giving a truthful eyewitness account of events in which he dreams of seeing a united and self-governed Arabia, the book turns out to be a version of the white man's image rather than an objective experience. It has nothing much to do with the title itself, and Lawrence's vision cannot materialize because of the betrayal of his government and the vision itself. As a result, this oriental text introduces promises to the Arabs that become "dead paper" because Lawrence's aim is not to appreciate the realistic life of Eastern society (Khan 2015: 361).

\subsection{Reductionism, Stereotyping and Schizophrenic Ego in $S P W$}

Lawrence declares quite clearly in the introduction to his book that he did not intend these events he narrates to be mistaken for history. Instead, he claims:

It is intended to rationalize the campaign, that everyone may see how natural the success was and how inevitable. ... My proper role was a minor one. ...In reality I never had any office among the Arabs. ... In these pages the history is not of the Arab movement, but of me in it" (SPW, 21, Emphasis added).

The Arab revolt represents a background to a private fiction for Lawrence. Actually, what is mentioned by Lawrence here raises a problem concerning the determination of the genre of the work itself. Perhaps unconsciously, though he disclaims writing history, he has inextricably welded the events he describes with his own ego. In this conception, the passage reveals the complicated process of the self/other relationship in the imperial model (Brandabur2016: 597).This projection of the ego makes Lawrence a manipulator of the Arabs so as to put himself at their head, and the meaning attached to the Arab Revolt is just how he designs it to be. Said suggests:

there is an unresolvable conflict in Lawrence between the White Man and the Oriental, and although he does not explicitly say so, this conflict essentially restages in his mind the historical conflict between East and West. Conscious of his power over the Orient, conscious also of his duplicity, unconscious of anything in the Orient that would suggest to him that history, after all, is history 
and that even without him the Arabs would finally attend to their quarrel with the Turks, Lawrence reduces the entire narrative of the revolt (its momentary successes and its bitter failure) to his vision of himself (Said 1978: 242).

Lawrence, in his frank introductory chapter, realizes the discursive authority that is customarily presumedby European writers in demonstrating foreign places and people. His uncertainty makes readers not to invest his story with more sureness than it emphasizes (Burton 2014: 37). In this regard, Lawrence virtually disclosesin a letter to his biographer Robert Graves that the section on Damascus "is full of half-truth,"like the famous incident at Derra, south of Damascus, where Lawrence describes how he is sexually abused and then whipped by the Turkish governor, Hajim Bey (quoted in Kaplan 1993: 53). Admitting that things never happened suggests that Lawrence seems to either exaggerate things or fantasize events to achieve certain purposes.

$S P W$ is an autobiography of a selective nature that serves the orientalist genre. Autobiography becomes confessional when it tends to select only those measures that the writer chooses to create an integrated shape, which serves the logic of his character and attitudes (Stevick 1967: 35). Lawrence selects those events which he desires (like those which reveal the Orient's inferiority). This selection, and the generalizations and reductive categories that derive from it, is what makes Lawrence an imperialist-orientalist figure. About this imperial agency of Lawrence, Kaplan writes:

During his whole period in Arabia, Lawrence's official status was always that of a political intelligence officer, who in the end did deliver the Arabs to Great Britain. Lawrence thought as an imperialist. He favoured the Balfour Declarations and the Zionist enterprise as a means to keep the French out of Palestine and perhaps out of the rest of Syria. ... He loathed the Turks and Frenchmen, and he respected the Jews (1993: 54).

Although Lawrence is a supporter of Arab independence, he also preferred Jewish capital and labor to be introduced into Palestine. He made a considerable part as an interpreter to make a meeting between the Zionist leader Chaim Weizmann and the Arab Emir Feisal, a meeting that led to endorsing the probability of Jewish claims to lands in Palestine. In a letter, Lawrence writes: "the sooner the Jews farm Palestine, the better" (Quoted in Falk 2006: 23). In $S P W$, he also notes that "only in ... the everlasting miracle of Jewry, had distant Semites kept some of their identity and force" (SPW, 31-32).

More specifically, Lawrence likens to the scholar William Robertson Smith whose vision of the world is binary. Smith describes the differences between the Arabian and Western traveller as follows:

The Arabian traveller is quite different from ourselves. The labour of moving from place to place is a mere nuisance to him, he has 
no enjoyment in effort [as "we" do], and grumbles at hunger and fatigue with all his might [as "we" do not]. You will never persuade the Oriental that, when you get off your camel, you can have any other wish than immediately to squat on a rug and take your rest, smoking, and drinking. Moreover, the Arab is little impressed by scenery [but "we" are] (Quoted in Said 1978: 242).

Writers like Lawrence reveal hostility and they fashion an irredeemable depiction of the Arabs and Muslims. Indeed, if the Oriental determines to negotiate from such a broad stereotype that controls the Western imagination, he has to play the Fool from King Lear. Binary opposition portrays the West as possessing ethics, reason and control while the East is infected by their opposites (Ramzy 2006: 88). In this way, Lawrence's fiction can be characterized by the presence of a 'Manichean allegory.' To put it simply, Manicheanism is a way of religious thinking which bases on the duality of light and darkness, good and evil. This binarist thinking is usually used to portray Western colonialism and its discourse about races. Colonialism bases on the duality of 'white and black' to reckon the black marginal, passive and therefore secondary to the discourse. According to Manichean allegory, the white are modern, civilized, advanced, and the black are savage, primitive, and backward. This category of simplistic binaristic and reductive stereotyping is the solid foundation of all colonial discourse and representation when dealing with Europeans and their Others (Nayar 2015: 101). Accordingly, SPW reflects the opposition between the presumed superiority of the European and the putative inferiority of the native. It is thus the field of diverse oppositions between civilization and savagery, self and other, good and evil, intelligence and emotion, subject and object (Reif-Hulser 1999: 158). In Manichean allegory, cultural or racial difference is, in Behdad's words, "transformed into moral and even metaphysical difference, investing the former with the power of an infallible master and reducing the latter to an exploited slave" (1997: 201).

Prominent writers of the twentieth century, like Lawrence, Wilfrid Blunt, Charles Doughty, Gertrude Bell, David Hogarth, St John Philby, Sir Mark Sykes and Ronald Storrs, brought their own intimate obsessions and mythology to such framework. In fact, as a white European writer, Lawrence is bound to the same general facts formulated by the anthropological, prototypical, linguistic and doctrinal forebears. The destructive power of this encounter inevitably exists, and even the professional involvement with the East does not prevent from despising it thoroughly. The central concern which engaged writers like Lawrence is to keep the orient under the control of the White Man. In his book, Lawrence projects a vision of the Orient, not a narrative of it, with the White Orientalist author as its prophet. This defeat of narrative by vision in $S P W$, is not something new. It is a continuation of a legacy. Edward Lane's Modern Egyptians is an earlier example. Here the Orientalist attempts to obtain a panoramic view of the Orient aiming to get hold of its society, history, mind, religion and culture (Said 1978: 237-9). 
The great drama of Lawrence's work denotes, in Said's words, "the struggle, first, to stimulate the Orient (lifeless, timeless, forceless) into movement; second, to impose upon that movement an essentially Western shape; third, to contain the new and aroused Orient in a personal vision whose retrospective mode includes a powerful sense of failure and betrayal" (Ibid.: 239). Lawrence says: "I meant to make a new nation, to restore a lost influence, to give twenty millions of Semites the foundations on which to build an inspired dream-palace of their national thought" $(S P W, 23)$. At first sight, the style is clear to the reader with respect to the political events of the period: to build a "dream-palace." However, the overall tone of Lawrence's style immediately changes in such a way that needs more analysis and clarification. Lawrence writes: "And we were casting them by thousands into the fire to the worst of deaths, not to win the war but that the corn and rice and oil of Mesopotamia might be ours" (SPW, 23). Yet, he adds, "I am afraid that I hope so ... . I am proudest of my thirty fights in that I did not have any of our own blood shed. All our subject provinces to me were not worth one dead Englishman" $(S P W, 23)$. In this episode, Lawrence introduces a multilayer map of noticeable elements of the text. The reason behind this is the abstract philosophical essence of sentences that put together other discussions in favour of one story or another. All this is targeted at delivering Lawrence's intended message and attitudes to his readership (Konurbaev 2016: 87-9).

When this movement fails in giving birth to "a new nation" or continent (because its dream of independence is invalidated), Lawrence becomes both a subjective consciousness and the mourning continent conveying a virtually cosmic disenchantment. In other words, what Lawrence presents to the reader is a non-mediated expert power which is the power to be the Orient for a short time. The historical events concerning the Arab Revolt are reduced to his experiences (Said, 1978: 243). The sense of defeat and failure is expressed by Lawrence himself. He states that: "There seemed no straight walking for us leaders in this crooked lane of conduct, ring within ring of unknown, shamefaced motives cancelling or double-charging their precedents" ( $S P W, 569)$. Lawrence's shame is connected with betraying the East since he always gives guarantee concerning English promises that he is well aware will not be fulfilled. What is fascinating is the situation he attaches himself to. He has no relation to the real world or the imaginary one. Simply, he is only connected to the power which he uses to project images into the real (Bewes 2011: 32-33).

There are many examples of Lawrencian reductive categories. The following passage is quoted as Lawrence emphasizes the for-ever and the inevitable inferiority of Arabs:

Arabs could be swung on an idea as on a cord; for the unpledged allegiance of their minds made them obedient servants. None of them would escape the bond till success had come, and with it responsibility and duty and engagements. Then the idea was gone and the work ended-in ruins. ... They were incorrigibly children of the idea, feckless and colour-blind, to whom body and spirit 
were forever and inevitably opposed. Their mind was strange and dark, full of depressions and exaltations, lacking in rule, but with more of ardour and more fertile in belief than any other in the world. They were a people of starts, for whom the abstract was the strongest motive, the process of infinite courage and variety, and the end nothing. They were as unstable as water, and like water would perhaps finally prevail. Since the dawn of life, in successive waves they had been dashing themselves against the coasts of flesh $(S P W, 41)$.

The identity of the Englishman in the East depends on remaining intact; therefore, any kind of threat to this plunges him into a state of instability and chaos. Continually, Lawrence keeps reminding himself that he is superior to and different from the society that he temporally places himself in. Lawrence is never able to consider that he experiences two educations and environments. No deep sense of understanding the Arabs arises inside himself. For him, they only serve as a vehicle to self-glorification and though he has chosen them as the people to lead, he does not reveal any sympathy or a sense of solidarity with their principles. "I was tired to death of these Arabs, petty incarnate Semites," he declares (Quoted in Kabbani 1986: 109-110). As Kabbani declares,

Lawrence may have felt the contagion of such lack of rule as he imagined thrived among the Arabs, as his chaotic and emotive narrative often points to. His writings were suspect in content and written to stir up emotions that do not correspond to the events described. But they proved invaluable to the manufacture of a hero, of a sentimental myth. The 'Lawrence of Arabia' fabrication kept the man from real scrutiny; it hid his weakness, his unreliability, and exaggerated what positive traits he possessed way beyond recognition (Ibid.: 110).

The description of the Arab mind reminds the reader of a book carrying the same title (i.e. The Arab Mind) by the twentieth-century Hungarian-Jewish anthropologist, Raphael Patai. By calling it an abstraction, Patai has given legitimization to the way of stereotyping which is carried through certain procedures of generalizations targeted at the mental characteristics of the Arabs as a population. He believes that "the Arab mind has been bent more on preserving rather than innovating, or maintaining than improving, or continuing than initiating." He adds, "For the Arab mind, there is even something sinful in engaging in long-range planning." He concludes, "To the Arab mind, eloquence is related to exaggeration" (Quoted in Barakat 1993: 183). The problem with such generalizations is that they are raised to a level of prestige and importance that assuresits correspondence with truth. In fact, it is the responsibility of cultural institutions to create such images of Others, and the binary opposition is built 
upon their difference from the Occident (Fields and Bronson 2009: 178). In this way,

The Orient ("out there" towards the East) is corrected, even penalized, for lying outside the boundaries of European society, "our" world; the Orient is thus Orientalized, a process that not only marks the Orient as the province of the Orientalist, but also forces the uninitiated Western reader to accept Orientalist codifications .... as the true Orient. Truth, in short, becomes a function of learned judgment, not of the material itself. (Appelrouth and Edles 2008: 832).

Again Lawrence vividly describes the mind of the Arab in these stereotypical terms:

This people was black and white, not only in vision, but by inmost furnishing: black and white not merely in clarity, but in apposition. Their thoughts were at ease only in extremes. They inhabited superlatives by choice. Sometimes inconsistents seemed to possess them at once in joint sway; but they never compromised: they pursued the logic of several incompatible opinions to absurd ends, without perceiving the incongruity $(S P W$, 36).

On another occasion, Lawrence looks down upon the whole history of Arabs' contribution to European modernity:

They were a limited, narrow-minded people, whose inert intellects lay fallow in incurious resignation. Their imaginations were vivid, but not creative. There was so little Arab art in Asia that they could almost be said to have had no art .... Nor did they handle great industries: they had no organizations of mind or body. They invented no systems of philosophy, no complex mythologies. They steered their course between the idols of the tribe and of the cave $(S P W, 21)$.

Further, Lawrence summarizes the whole narrative of $S P W$, showing clearly his contempt for Arabs' life:

It is a narrative of daily life, mean happenings, little people. Here are no lessons for the world, no disclosures to shock peoples. It is filled with trivial things, partly that no one mistake for history the bones from which someday a man may make history, and partly for the pleasure it gave me to recall the fellowship of the revolt $(S P W, 22)$. 
By admitting that there are "no lessons" to be found in the story and that the events are trivial, Lawrence himself declares that the subject position of the epichero is inaccessible to him, and likewise to the epic writing one. The inaccuracy of dealing with the actual events determines his psyche, and in turn determines the content of the text (MacCabe, Murray and Warner2011: 161). Lawrence centralizes his role individually in the campaign and embraces the subjective. In doing so, he makes a selection that is "reduced" to the trivial and everyday life. Besides, he emphasizes the 'fellowship' of the revolt', and the influence of the landscape in the desert, both sustained themes encompassing his delight in the admiration of and proximity to the bodies of other men. This preoccupation in the play of difference and recognition makes him express the pleasure in living many lives. Simultaneously he becomes exposed to accusations of instability, of lack of truthfulness, of inauthenticity (Crisp, Ferres and Swanson 2000: 195).

In Lawrence's writing, there are even difficulties and a sense of hesitancy about making them available to the public. The reason behind this is not only that they are preoccupied with sexual ambivalence, but a deeper problem results from the imbrication of personal narratives of moral introspection, psychological development, and cultural identification with the public narratives of history. Actually, the subjective narrative of $S P W$ is derogated by Lawrence and it bothers the conventions of military histories. The book thereby offers a look at his 'troubled persona' (Ibid.: 194). To validate such argument, one can notice the purpose given by Lawrence concerning writing $S P W$. First, he states that the book is a "designed procession of Arab freedom from Mecca to Damascus,' and it was about an 'Arab war waged and led by Arabs for an Arab aim in Arabia.' However, after some paragraphs, he declares that the pages written are not about the history of the Arab movement, "but of me in it" $(S P W, 22)$. At first glance, the reader recognizes that Lawrence's determination combines both private and public dimensions, showing a clear split intention. Suddenly then, he refutes the assertion of authoritative and historical documentation, a state which suggests that he is unable to move beyond the actual (Crisp et al. 2000: 195).

Furthermore, in another racist passage Lawrence compares between the Arab and the Englishman showing how the Englishman is far superior to the Arab Bedouin, a savage who can never be civilized:

The Bedu were odd people. For an Englishman, sojourning with them was unsatisfactory unless he had patience wide and deep as the sea. They were absolute slaves of their appetite, with no stamina of mind, drunkards for coffee, milk or water, gluttons for stewed meat, shameless beggars of tobacco. They dreamed for weeks before and after their rare sexual exercises, and spent the intervening days titillating themselves and their hearers with bawdy tales. Had the circumstances of their lives given them opportunity they would have been sheer sensualists. ... If forced into civilized life they would have succumbed like any savage race to its diseases, meanness, luxury, cruelty, crooked dealing, 
artifice; and, like savages, they would have suffered them exaggeratedly for lack of inoculation $(S P W, 226-227$, Emphasis added).

About their skills, Lawrence declares: "I concluded that the tribesmen were good for defense only. Their acquisitive recklessness made them keen on booty, and whetted them to tear up railways, plunder caravans, and steal camels; but they were too free-minded to endure command, or to fight in team. (SPW, 106).

Reading Lawrence's book, the reader is faced with astonishing events that reveal the instability of dealing with truth. Lawrence's real ego is manifested as moving through the life of the Orient, to picture details, to register their traditions and customs but using these as a Western device. No doubt the local inhabitants of the desert live in harmony with the natural world, though in deplorable conditions and hard times. Yet, Lawrence seems to display endurance that evokes his British heroism. Lawrence did not protect himself from the dangers of desert life as his Arab fellows did. Pain here is just a measure of his ability to stay alive in dangerous circumstances. Though suffering is thrust upon him, endurance is a "condition of his own creation" (Goodheart, 2004: 143). Referring to the sandy, hot and dry local wind known as "Khamsin", Lawrence says:

For my own part, I always liked a Khamsin, since its torment seemed to fight against mankind with ordered conscious malevolence and it was pleasant to outface it so directly, challenging its strength, and conquering its extremity. There was pleasure also in the salt sweat-drops which ran singly down the long hair over my forehead, and dripped like ice-water on my cheek $(S P W, 254)$.

What is more, in a passage that foreshadows his ultimate disillusion, Lawrence alludes to Jonathan Swift's Gulliver's Travels to describe his state of mind by the end of the war, ultimately repeating conventional stereotypes about Arabs:

A man who gives himself to be a possession of aliens leads a Yahoo life, having bartered his soul to a brute-master. He is not of them. He may stand against them, persuade himself of a mission, batter and twist them into something which they, of their own accord, would not have been. Then he is exploiting his old environment to press them out of theirs. Or, after my model, he may imitate them so well that they spuriously imitate him back again $(S P W, 29)$.

Lawrence here describes that a person whose "two selves converse in the void" is subject to near madness. The Yahoos in Swift's Travels represent creatures with brutish behavior though they have a human shape, a condition that reflects deep hostility in describing the Arabs as if they are beasts. This situation 
designates the void of conversing between two incompatible selves, because for him it represents the otherness of others and; therefore, an outsider is unable to be "of them" genuinely. What is interesting is there is a further articulated contradiction in Lawrence's description of the ties to his Arab companions, since he pictures them brightly as "the fellowship of the revolt." Yet, the same ties epitomize the reason that subjects him to "a Yahoo life" (Seigel 2016: 75).

Another situation is when Lawrence decides to go to Akaba alone, one that exemplifies his self-conceived role of rebel-insider: "I decided to go my own way, with or without orders" (SPW, 233). Thus Lawrence's metamorphosis from army officer into his version of latter-day nomad warrior shows him to be an illegitimate and disquieting character who is characterized by an essential indiscipline: The nomad warrior is put in the position of betraying, among other things, the role of the military (Kaplan 1995: 1).

Lawrence's adoption of Arab dress and custom while joining the Arab Revolt reflects what is called "double mimesis." This "cultural impersonation," as Zabus puts it, "masked a will-to-power, a desire to outdo the Arabs in their 'Arabness,' an ambition to become more truly other than the Other" (2013: 58). Lawrence also internalizes the conception of Arabs concerning victory: "To an Arab an essential part of the triumph of victory was to wear the clothes of an enemy" ( $S P W, 314)$. Such conception demonstrates how mimesis may be organized to "counter a prescribed identification" (Zabus 2013: 58). Instances of double mimesis so common to the literature of the colonial experience express Lawrence's failure to bridge the difference and to join with the tribesmen he once admired. To live a yahoo existence may be most simply to surrender civilized behaviour and dignity merely for the sake of joining a barbarous culture, in which case Lawrence is merely repeating conventional stereotypes (Halloran 2001: 185). Like Gulliver, he has seen and lived through so much barbarism that he loses his own identity and sense of place:

In my case, the effort for these years to live in the dress of Arabs, and to imitate their mental foundation, quitted me of my English self, and let me look at the West and its conventions with new eyes: they destroyed it all for me. At the same time I could not sincerely take on the Arab skin: it was an affectation only. Easily was a man made an infidel, but hardly might he be converted to another faith. I had dropped one form and not taken on the other, and was become like Mohammed's coffin in our legend, with a resultant feeling of intense loneliness in life, and a contempt, not for other men, but for all they do. Such detachment came at times to a man exhausted by prolonged physical effort and isolation. His body plodded on mechanically, while his reasonable mind left him, and from without looked down critically on him, wondering what that futile lumber did and why. Sometimes these selves would converse in the void; and then madness was very near, as I believe it would be near the man who could see things through the 
veils at once of two customs, two educations, two environments $(S P W, 30)$.

As the quotation vividly reveals, Lawrence has to become one of the Arabs so as to lead them successfully into victory. In an incident when some English soldiers join the Arabs on the march to Damascus, he attempts to imitate them so well. However, though he succeeds in his pretense as an Arab, his Western breed and conscience prevent him from continuing to disguise under the Arab cover. As he declares in the book, "My will had gone and I feared to be alone, lest the winds of circumstance, or power, or lust, blow my empty soul away" (SPW, 514). This process is the main cause of the mental suffering from which he is unable to escape. Therefore, Lawrence ended by losing all sense of identity (Stang 2002: 81).

\subsection{Orientalist strategies in $S P W$}

One of the strategies that a character uses in an orientalist text to obtain favours is improvisation, "the apparent empathy of one who uses his knowledge of a culture's beliefs in order to turn them to his own purposes. What makes improvisation possible," as Greenblatt believes, "is the ability and willingness to play a role, to transform oneself, if only for a brief period and with mental reservations, into another. This necessitates the acceptance of disguise. Such roleplaying in turn, Greenblatt adds, "depends upon the transformation of another's reality into a manipulable fiction" (Greenblatt 1980: 228). Lawrence as a character uses improvisation for controlling and owning the Arabs.

Indeed, role-playing is what Lawrence admits to have done. Throughout $S P W$, role-playing and playacting are used as mechanisms to Lawrence's activities in the campaign. Before Arab eyes, he claims, "I must play out my tedious part" $(S P W, 467)$. While sitting in a mixed company with Feisal, he admits to throw "apples of discord" and "inflammatory subjects" just to sound their "mettle and beliefs without delay" (SPW, 100). He acknowledges the "fraudulence which had to be my mind's habit: that pretence to lead the national uprising of another race, the daily posturing in alien dress, preaching in alien speech" $(S P W, 514)$. Accordingly, Lawrence begins to experience a burden within himself, feeling that his situation resembles living a lie. The man who once expresses that he is "tired to death of these Arabs," laments himself bitterly for the disastrous failure. He feels himself in the wrong situation of leading a national uprising of people who are from "another race," and he also feels that the senseless deaths resulting from the slaughter at the town of Tafileh deprives achieving wishful thoughts. "We glozed our fraud by conducting their necessary war purely and cheaply. But now this gloss had gone from me. Chargeable against my conceit were the causeless, ineffectual deaths of Hesa" (SPW, 514). What is worth noting now is that the assumed hero is not a person of action, rather he is one who is unable to free himself from the deceit.

In 1918, Lawrence takes a new part to help the Arab Northern Army, which is led by Feisal and under the command of Allenby, a British imperial governor. 
The role is to harry retreated Turkish Army. Now he suffers nervous strain, especially after his brief arrest by the Turks at Deraa and his assumption that "the citadel of my integrity had been irrevocably lost" (SPW, 456). Yet, though he accuses himself of fraudulence and deceitfulness, he has to take his role since Allenby needs him to take Damascus and Aleppo, if possible. He concludes: "I must take up again my mantle of fraud in the East . . . . It might be fraud or it might be farce: no one should say that I could not play it" ( $S P W, 515)$. Lawrence succeeded in weaving a web of fictions and feints to persuade the Turkish authorities that Allenby's raids were coming East in the direction of Amman rather than north to Galilee (Ranklin 2008: 118). Lawrence declares an important point concerning the deceptive role played by England, France and Russia, as it is decided in the Sykes-Picot agreement. Though he knows that this agreement takes no account of Arab nationalism, he convinces Feisal that "his escape was to help the British so much that after peace they would not be able, for shame, to shoot him down in its fulfillment" $(S P W, 572)$.

The result of Lawrence's action is, of course, failure, notably psychological conflict and schizophrenia. Lawrence reflects "an unresolvable conflict between the White Man and the Oriental", which "essentially restages in his mind the conflict between East and West". To read $S P W$ as a "great imperial narrative," is to see the fictive self of the author emerging through a painful process of discovery (Said 1978: 242). Lawrence's narrator is uneasy with the "self" he discovers, "I did not like the "myself' I could see and hear," he remarks at one point $(S P W, 584)$. It becomes clear that the image which he once stereotypes is the same one that he tries to take, yet, now he feels as an outsider and wishes to extricate the imprisoned self, since his home-sickness stresses vividly the outcast life among the Arabs. This point reminds the reader of the same situation that Leo Tolstoy's madman goes through: "I am running away from something dreadful and cannot escape it. I am always with myself, and it is I who am my tormentor. . . . It is myself I am weary of, and find intolerable and a torment" (Tolstoy2001: 786). The reason behind Lawrence's state is mainly because he "exploited their higher ideals and made their love of freedom one more tool to help England win" $(S P W, 560)$. Accordingly, the myth that Lawrence attempts to create is set into its suitable tradition when he is ranked as a nineteenth-century imperialist hero (Nash 2005: 194).

Lawrence even attempts, stylistically, to impose a Western flavor over his Orientalist strategy in almost everything: the text, the author, and the title in order to make the unfamiliar known to the Orientalist. For example, in order to live amongst the other, Lawrence had to interpret the Other in terms of a Western familiar experience. Carola Kaplan expresses this point:

Paradoxically, in order to inhabit the Arabia of his imagination, Lawrence had first to convert the Other into the familiar. He did so by interpreting the Arab world as an earlier and simpler version of the Western culture that had produced him. The Arabia of Lawrence is in fact his idealized version of medieval Western 
society. Thus Lawrence manages to contain or to colonize the space of the Other within the confines of the already known (Kaplan 1995: 3).

In fact, for Lawrence if anything is good or healthy, it ethically belongs to Europe, like the remote hills of Yemen: "Ethically, these fertile healthy hills were in Europe, not in Asia" $(S P W, 33)$. In this sense, one can capture "the dominant power relationship inherent in traditional Western and non-Western relations," in this case between Britain and the Arabs: "There are Westerners and there are Orientals. The former dominate; the latter must be dominated, which usually means their lands occupied, their internal affairs rigidly controlled, their blood and treasure put at the disposal of one or another Western power" (Sheeran 2007: 142).

Even the whole book about the Orient is modeled after a Western text. It is largely modeled after the plot, structure, and themes of Sir Thomas Malory's Le Morted' Arthur (the only book that Lawrence carried with him throughout the desert campaign), serving as the protonarrative for Lawrence's interpretation of Arab culture and of his own role in shaping the future of Arabia and thereby justifying neocolonialism. This is significant because serving as the protonarrative for the Arab revolt, the Le Morte d' Arthur provided Lawrence with a ready-made scenario for action, with a justification for his role in the campaign, and with a rationale for Britain's intervention in the history of another people. Through this narrative, Lawrence considers himself engaged in the chivalric enterprise of righting a wrong done to another people by helping the Arabs to overthrow the tyranny of the Turks. Add to that, Lawrence uses this Arthurian narrative to describe himself as the Westerner who will help Arabs overcome their limitations. For example, he refers to his "more than Palomides' pains" $(S P W, 219)$ while describing his futile efforts to help Abdullah, Feisal's brother, overcome his personal limitations in the interests of the larger revolt. His allusion to Palomides calls to mind Sir Palomydes from Le Morte De Arthur, a Saracen who travels through the Christian realms of chivalry showing the baptized knights how an extremely pagan can exceed their highest ideas. The Arthurian Palomides, as an infidel amongst believers, fittingly represents Lawrence's alien status among the Arabs and his affinity and admiration of the Bedouins' rigorous code of honour. Lawrence assumes the Palomides role in the design and execution of the Arab Revolt.

Also the Arabian Desert is likened to Eliot's Waste Land, a reminder of the loss of cohesion and context from the past and the shattered condition of the present which "captures the desolation, disillusionment and spiritual bankruptcy of the post-war generation" (Abu Ssaydeh2019:340). Lawrence says: "It was good for the Arab Revolt that so early in its growth this change imposed itself. We had been hopelessly labouring to plough waste lands" (SPW, 336).

Lawrence's orientalist discourse narrative uses the title as an allusion to a religious text that emphasizes the Western superiority. The source which is essentially responsible for enlightening mankind is represented by a woman who 
is personified as wisdom."Wisdom hath builded a house; ... she hath hewn out her seven pillars. Give instruction to the wise man, and he will yet be wiser: teach a just man, and he will increase in learning" (Proverbs 9:1,9). It is the Western wisdom of the White Man which will enlighten Arabia.

The aim of Lawrencian Orientalist strategies and reductive categories was to control and own the Arabs as well, an aim for which Lawrence had to adopt certain strategies in $S P W$. For he had to convince the Arabs that his view of the campaign and theirs were the same, that his interpretation of Arab culture was in fact their reality: "The Arab cause which was theirs by sentiment, and instinct and inclination, became theirs by interest also. Slowly our example and teaching converted them: very slowly, by their own choice, that they might be ours more surely" $(S P W, 446)$.

By the end of $S P W$, Lawrence acknowledges the utter separateness of his personal enterprise from the Arab undertaking. As the newly united Arabs are called by the Muedhdhin to prayer to celebrate the occupation of Damascus, he laments his loss of cultural dual citizenship: "My fancy, in the overwhelming pause, showed me my loneliness and lack of reason in their movement: since only for me, of all the hearers, was the event sorrowful and the phrase meaningless" $(S P W, 674)$. The passage suggests that $S P W$ is full of "dubious absolutes." The reader here begins to question whether this is really the first night of perfect freedom. It is also astonishing to find that Lawrence presumes that the event is sorrowful only for him. He is now a modern Odysseus in his hopeless quest (Giddings 1991: 168-9).

\section{Conclusion}

$S P W$ is not a travel narrative or history in the true sense of the term because Lawrence, the writer, does not fashion a truthful account of the journey he made in Arabia. He registered details about the life of the Arabs but with the colonizer's eyes. What he gives in his novel is an Orientalist text which is clothed with the intrinsically idiosyncratic characteristics of Orientalism as a literary Eastern trend. Bearing the Manichean allegory in his mind, he relies heavily on reductionism and stereotyping which reflect hatred, prejudices and racism towards the Arabs. He categorizes Arabs as lazy, irrational, evil and chaotic nation. Reproducing these stereotypes by European writers like Lawrence is a means to justify the expansion of the imperial power, since the process of using the Orientalist discourse has nothing to do with the actual representations of the Orient. Rather, obtaining knowledge of the other provides more power over it. What must persist then is the emphasis on the binary oppositions, i.e., the distinction that reveals the superiority of the West over the inferiority of the Orient. Lawrence reflects a modern way of writing to present the cultural hegemony implemented by the West to generate a structure of knowledge appealing to the imperial mind. Accordingly, regarding his work as an honest, truthful, and objective piece of work is practically and anthropologically an impossibility. Like the Arab who is regarded as a project, he himself has a project to complete in the formation and fabrication of a myth. 
$S P W$ is doomed to be subjective and inexact because Lawrence's attitude changes ironically in some paragraphs and his account is mixed with woven and emotionally-built incidents. Though he fashions his presence as a spiritual source of the Arab revolt, the range of his Colonial discourse is just a tool to illuminate the inevitable representation of the Orient as Other. In fact, he appears as a synthesis of two conflicting personalities; the man of $S P W$ and the one depicted in his letters, because he relates incidents that contradict those reported in his letters or by contemporaries.

Lawrence's attempts to adopt the Eastern way of life throughout double mimesis is just a road to bring to mind the mystic heroism of the British empire and to create an image of Western superiority over the inferiority of the East. The work configures a conflict between the author's vision and the narrative history. Basically, the embracement of the Arab lifestyle could not cover the imperial mask and discloses the reason that makes him willing to "orchestrate" the Arab revolt.

Lawrence rests on Orientalist strategies to make his work functional in the implementation of the discourse of the imperial project. As a fictional protagonist, he depends on the strategy of improvisation to tighten his imperial grip over Arabs and the people of the East in general. His role-playing assists him a great deal in putting the mask over his colonial intentions but not forever because he ultimately fails at his errand due to his psychological conflict and schizophrenia. As a Western writer, he also relies on the strategy of inserting Western elements in the design, title and authorship of his text. In doing so, he makes a substantial contribution in the construction of Western perspectives that developed throughout a long time about the Orient.

Arkan Naser Hussain

The General Directorate of Education in Al-Qadisiyah Province, Ministry of Education, Iraq

ORCID Number: 0000-0001-8843-5866

Email: dreamaamn@yahoo.com

Hassan Qanood Jabir

The General Directorate of Education in Al-Qadisiyah Province, Ministry of Education, Iraq

ORCID Number: 0000-0003-4881-1593

Email: achrish@yahoo.com

Noor Kadhoum Jawad

The General Directorate of Education in Al-Qadisiyah Province, Ministry of Education, Iraq

ORCID Number: 0000-0001-7784-3370

Email:nuralkaabi@yahoo.com 


\section{References}

Abu Ssayde, Abdul Fattah. (2019). 'Translating Intertextuality in T.S. Eliot's The Waste Land'. International Journal of Arabic-English Studies (IJAES), 19 (2): 339-358. https://doi.org/10.33806/ijaes2000.19.2.6 (Retrieved on 16 February, 2021).

Appelrouth, Scott and Laura Desfor Edles. (2008). Classical and Contemporary Sociological Theory: Text and Readings. New Delhi: Pine Forge Press.

Barakat, Halim. (1993). The Arab World: Society, Culture, and State. Berkeley, CA: University of California Press.

Behdad, Ali. (1997). "Eroticism, Colonialism, and Violence". In Hent de Vries and Samuel Weber (eds.), Violence, Identity and Self-Determination. Standford, Standforn University Press.

Bewes, Timothy. (2011). The Event of Postcolonial Shame. New Jersey: Princeton University Press.

Brandabur, A. Clare. (2016). Time's Fool: Essays in Context. Barry Charles Tharaud (ed.). Cambridge: Cambridge Scholarship Publishing.

Burton, Stacy. (2014). Travel Narrative and the Ends of Modernity. New York: Cambridge University Press.

Crisp, Jane, Kay Ferres and Gillian Swanson, (eds.).(2000). Deciphering Culture: Ordinary Curiosities and Subjective Narratives. London: Routledge.

Falk, Gerhard. (2006). The Restoration of Israel: Christian Zionism in Religion, Literature, and Politics. New York: Peter Lang Publishing.

Fields, Tina R. and Matthew C. Bronson, (eds.) (2009). So What? Now What? The Anthropology of Consciousness Responds to a World in Crisis. Newcastle: Cambridge Scholars Publishing.

Giddings, Robert, (ed.). (1991). Literature and Imperialism. New York: Palgrave Macmillan.

Goodheart, Eugene. (2004). Novel Practices: Classic Modern Fiction. New Jersey: Transaction Publishers.

Greenblatt, Stephen. (1980). Renaissance Self-Fashioning: From More to Shakespeare. Chicago: University of Chicago Press.

Halloran, William D. (2001). Titan, Tome, and Triumph: T.E. Lawrence's Seven Pillars of Wisdom as a Modernist Spectacle, Unpublished $\mathrm{PhD}$ Diss. University of California, Los Angles. United Sates of America. 
Hill, Charless. (2011). Trial of a Thousand Years: World Order and Islamism. California: Hoover Institution Press.

Kabbani, Rana. (1986). Europe's Myths of Orient: Devise and Rule. London: The Macmillan Press.

Kaplan, Carola M. (1995). "Conquest as Literature, Literature as Conquest: T. E. Lawrence's Artistic Campaign in Seven Pillars of Wisdom." Texas Studies in Literature and Language, vol. 37, no. 1, pp. 7297. www.jstor.org/stable/40755061 (Accessed 17 August, 2020).

Kaplan, Robert. (1993). The Arabists: The Romance of American Elite. New York: The Free Press.

Khan, Jalal Uddin. (2015). Readings in Oriental Literature: Arabian, Indian, and Islamic. New Castle upon Tyne, UK: Cambridge Scholars Publishing.

Konurbaev, Marklen E. (2016). The Style and Timbre of English Speech and Literature. London: Palgrave Macmillan.

Lawrence, T. E. (1940). Seven Pillars of Wisdom. Delhi: Oxford University Press.

MacCabe, Colin, Kathleen Murray, and Rick Warner, (eds.). (2011). True to the Spirit: Film Adaptation and the Question of Fidelity. Oxford: Oxford University Press.

Nash, Geoffrey. (2005). From Empire to Orient: Travellers to the Middle East $(1830-1926)$. London: I.B. Tauris.

Nayar, Pramod K. (2015). The Postcolonial Studies Dictionary. West Sussex: John Wiley \& Sons.

Ramzy, Rasha I. (2006). "Historiography as a Means for Power: "Otherization" and Imperialism through the Writing of Edward Said. In Silvia NagyZekmi, (ed.), Paradoxical Citizenship: Edward Said. Lanham, Md.: Lexington Books.

Ranklin, Nicholas. (2008). A Genius for Deception: How Cunning Helped the British Win Two World Wars. Oxford: Oxford University Press.

Reif-Hulser, Monika, (ed.) (1999). Borderlands: Negotiating Boundaries in Post-colonial Writing. Amsterdam: Rodopi.

Said, Edward W. (1978). Orientalism. New York: Vintage.

Seigel, Jerrold. (2016). Between Cultures: Europe and Its Others in Five Exemplary Lives. Pennsylvania: University of Pennsylvania Press.

Sheeran, Paul. (2007). Literature and International Relations: Stories in the Art of Diplomacy. London: Routledge.

Stang, Charles M., (ed.). (2002). The Waking Dream of T.E. Lawrence: Essays on His Life, Literature, and Legacy. New York: Palgrave.

Stevick, Philip, (ed). (1967). Theory of the Novel. London: The Free Press.

Tolstoy, Leo. (2001). Collected Shorter Fiction, Vol. 1. New York: Everyman's Library.

Yun, Koo Dong. (2012). The Holy Spirit and Ch'i (Qi): A Chiological Approach to Pneumatology. Eugene: Pickwick Publications. 
Zabus, Chantal. (2013). Out in Africa: Same-sex Desire in Sub-Saharan Literatures and Cultures. Suffolk: Boydell\& Brewer Ltd. 